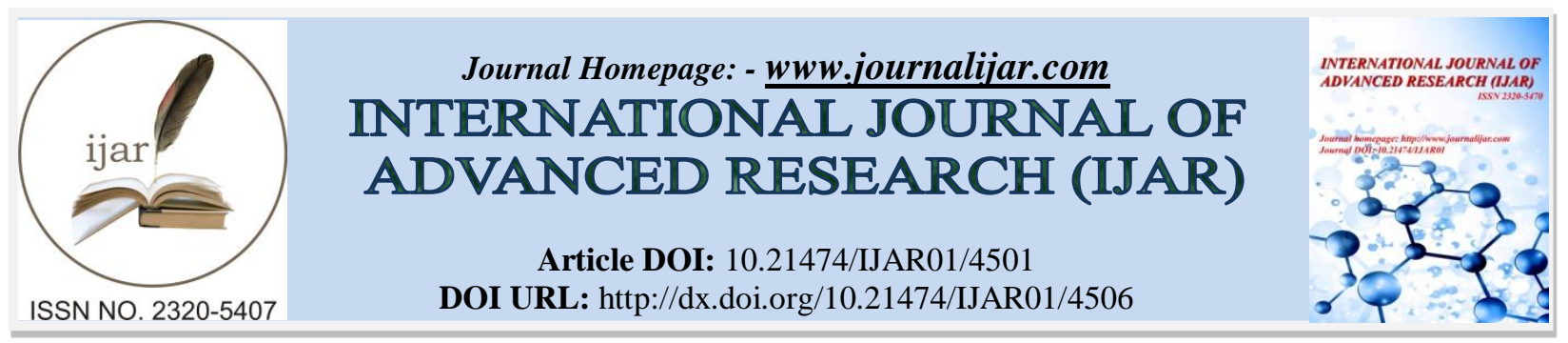

RESEARCH ARTICLE

\title{
BIOFUNGICIDES AN EFFICIENT ALTERNATIVE CONTROL STRATEGY AGAINST MANGO ANTHRACNOSE IN SENEGAL.
}

Yaya Diallo ${ }^{1}$, Papa Madiallacke Diédhiou ${ }^{1}$, Elizabeth Bush $^{2}$, Mizuho Nita ${ }^{2}$ and Anton Baudoin ${ }^{2}$.

1. UFR des Sciences Agronomiques d'Aquaculture et des Technologies Alimentaires (UFR S2ATA), Universite Gaston Berger de Saint-Louis (UGB), Saint-Louis, Senegal

2. Virginia Polytechnic Institute and State University in Blacksburg, Virginia, USA

\section{Manuscript Info}

............................

Manuscript History

Received: 16 April 2017

Final Accepted: 18 May 2017

Published: June 2017

Key words:-

mango, Mangifera indica, anthracnose control, Colletotrichum gloeosporioides, azoxystrobin, thiophanate methyl, Serenade, Sonata

\section{Abstract}

Mango production in the South of Senegal is exposed to intensive rainfall from late May to October, with high temperature and moisture levels. These conditions are conducive for the development of anthracnose caused by Colletotrichum gloeosporioides (sensu lato) causing huge losses in the field and after harvest. The incidence of anthracnose is very high in the agroclimate of Casamance during the rainy season. Premature fruit drop, pre- and postharvest fruit spots and fruit rot are the usual symptoms of mango anthracnose. Attempts to control the disease with biofungicides were carried out. Protective treatments with the biofungicides allowed reducing significatively the incidence of the disease as well as its severity. The protective effect of the biofungicides was rated almost as good as that of conventional fungicides. When applied for curative action on naturally infected mangoes, the biofungicides Sonata and Serenade were found very efficient; they were nevertheless a bit less effective than the conventional fungicides thiophanate methyl and azoxystrobin.

Copy Right, IJAR, 2017,. All rights reserved.

\section{Introduction:-}

The main mango producing areas in Senegal are located in the north (Niayes area) and the south (Casamance) of the country. The Niayes area (the coastal area between Dakar, Thies, and Saint-Louis) accounts for $80 \%$ of export mango volume (Mbaye et al, 2006). The Casamance (Ziguinchor, Sedhiou, and Kolda) area however is the strongest provider of the domestic markets and rates second as a contributor for export mango. Mango is commercialized in the international market in a highly competitive environment in terms of quality and standards. In order to meet the demand of consumers for tasty, healthy, perfect fruits without flaws, in one hand, but also containing no or low pesticide residues, growers must resolve conflicting issues during production and transit processes. They need to produce fruit of the desired quality, in accordance with regulations and specifications, without neglecting the yield, needed to guarantee profitability. Despite the production potential in Senegal, environmental conditions favoring pathogens in the field and after harvest, interfere with the ambitious goal to produce substantial tonnages of a high quality product, which satisfies the stringent export quality standards.

Fungi often cause most of mango diseases. The early stages of infection occur in the field and result in fruit rot during ripening and storage. In Senegal, fungi play an important role in post-harvest rot of mangoes and generate

Corresponding Author:- Yaya Diallo. 
significant financial losses (Mbaye et al, 2006; Diedhiou et al., 2007). Among the fungal diseases causing fruit rot, anthracnose is the most important mango disease. Depending on the agro-climatic zones and the occurrence of rainfall, the disease can lead to heavy losses (Diedhiou et al., 2014b). The consequences of the disease are a shortening of the export window, and high risks of cargo rejection at port of entry in the importing country. This leads to important immediate financial consequences as well as a long-term loss of market shares.

Several fungicides have become available to control infections as well as protect against their establishment (Kumar et al., 2007). Preharvest spraying of these products can prevent the establishment of quiescent infections before harvest and reduce disease pressure. There are many reports on the efficacy of azoxystrobin and thiophanate methyl against anthracnose on mangoes (Diedhiou et al., 2007; Diedhiou et al. 2014a; Sundravadana, 2006).

However, because of health and environmental concerns, alternative approaches such as resistant cultivars, cultural practices, and biofungicides are being developed to control diseases. (Conway et al., 1991; Sugar et al., 1997; Wilson et al., 1997; Janisiewicz et al., 2002; Hewajulige et al., 2010). Reports of efficacy of such methods in the field have been limited until Govender et al (2006) demonstrated that Bacillus licheniformis was able to control mango anthracnose. Senghor et al (2007) showed that $B$. subtilis reduced the incidence of anthracnose on ripening, bagged mangoes significantly. Moreover, Peralta (2004) showed that B. subtilis (QST 713 strain) had excellent performance in reducing the severity of anthracnose on mango.

The purpose of this study was to examine the efficacy of biological control products to control mango anthracnose.

\section{Materials and Methods:-}

Protective application of biofungicides against mango anthracnose:-

An isolate of Colletotrichum gloeosporioides, obtained from anthracnose- infected mangoes was used. Disease free mango fruits were purchased in the market. Prior to inoculation, half of the surface was wounded with approximately 50 punctures, using a sterile scalpel, to a depth of approximately $10 \mathrm{~mm}$. The fruits were thereafter sprayed with Sonata (Bacillus pumilus strain QST 2808, $1.17 \mathrm{ml} / 100 \mathrm{ml}$ of sterile deionized water) or Serenade $(0.25 \mathrm{~g} / 100 \mathrm{ml})($ table 1$)$. The non-treated control mangoes were sprayed with sterile deionized water.

The mangoes were thereafter placed in plastic boxes and incubated at room temperature for 2 days. They were then inoculated with the isolate of Colletotrichum gloeosporioides. Inoculation was performed by spraying the fruit with a spore suspension from a 7-day old culture on PDA set to contain $27 \times 10^{3}$ spores $/ \mathrm{ml}$ using a hemacytometer. They were incubated in the same conditions with high humidity maintained by spraying sterile water. Four mangoes were used for each treatment, and there were three replications. The same experiment was conducted on non-wounded mangoes and disease incidence and severity were recorded at the end of the experiment, 8 days after inoculation.

\section{Curative effect of biofungicides against mango Anthracnose:-}

Mature but not unripe mangoes of the variety kent were picked from the orchard in Djibelor (Ziguinchor) in midAugust. They were assumed to have been exposed to the natural inoculum at least two months after onset of the rainy season. It is known that the incidence of anthracnose in the rainy season in the agroclimate of Casamance can reach 100\% (Diedhiou et al, 2015). Some of the mango fruits already showed lesions, but only mangoes without visible lesions were selected for the experiment. One hundred $\mathrm{ml}$ spray material was prepared at the concentrations reported in Table 1. Treatments were applied by spraying the whole surface of the fruit, with a total of 15 fruits each. After treatment, the fruits were allowed to dry for 2 hours, and incubated in the laboratory at room temperature.

Table 1:- Treatments rates applied in the north and the south.

\begin{tabular}{|l|l|l|l|l|}
\hline Treatment & $\begin{array}{l}\text { Formulation and company } \\
\text { information }\end{array}$ & a.i./hectare & $\begin{array}{l}\text { a.i. in 10 L water per } \\
3 \text { trees in the south }\end{array}$ & $\begin{array}{l}\text { a.i. in 10 L water per } \\
3 \text { trees in the north }\end{array}$ \\
\hline Azoxystrobin & Ortiva 250 SC (Syngenta) & $425 \mathrm{ml}$ & $13 \mathrm{ml}$ & $11 \mathrm{ml}$ \\
\hline $\begin{array}{l}\text { Thiophanate } \\
\text { methyl }\end{array}$ & Fongsin 450 SC (Savana) & $\begin{array}{l}1,134 \\
\mathrm{ml}\end{array}$ & $36 \mathrm{ml}$ & $30 \mathrm{ml}$ \\
\hline $\begin{array}{l}\text { Bacillus pumilus } \\
\text { QST 2808 }\end{array}$ & Sonata (Bayer) & $\begin{array}{l}4,732 \\
\mathrm{ml}\end{array}$ & $142 \mathrm{ml}$ & $117 \mathrm{ml}$ \\
\hline $\begin{array}{l}\text { Bacillus subtilis } \\
\text { QST 713 }\end{array}$ & Serenade Optimum (Bayer) & $992 \mathrm{~g}$ & $30 \mathrm{~g}$ & $25 \mathrm{~g}$ \\
\hline
\end{tabular}




\section{Disease Evaluation:-}

After treatment, the fruits were maintained in a clean and ventilated area at room temperature $\left(26-29^{\circ} \mathrm{C}\right)$ on a benchtop. The number of anthracnose lesions was recorded every 2 days to distinguish coalesced lesions from individual ones, for a total of 8 days. Each treatment consisted of three replicates with a total of 15 fruits, and the number of lesions for each replication were used for statistical analysis.

The mean disease lesion count per fruit and number of disease-free fruits per treatment were analyzed with the generalized linear mixed model procedure (PROC GLIMMIX) of SAS version 9.4 (Cary, NC, USA). For the number of disease-free fruits, a negative binomial distribution was assumed, and for the disease lesion counts, a Poisson distribution was assumed. Once the effect of treatment was found to be significant, Fisher's least square difference (LSD) was used for the mean separation.

\section{Results:-}

Protective application of biofungicides on mango anthracnose:-

Inoculation with C. gloeosporioides led to the development of anthracnose (Table 2). The disease was not recorded on not inoculated control mangoes. Wounding the fruits prior to inoculation did not lead to higher infection. In the contrary inoculated non-wounded fruits had more lesions per fruit. The effect of wounding was however not significative at $95 \%$ confidence interval. The mean number of lesions per fruit in the inoculated control was significantly higher than for mangoes submitted to the other treatments. Likewise 138 lesions were recorded for the control while the number dropped down to 15 and 12 lesions per fruit respectively for the treatment with Sonata and Serenade.

For mangoes inoculated with $C$. gloeosporioides, the number of disease free fruits at the end of the experiment varied from 3 for the inoculated control to 2.5 for fruits treated with biofungicides. The difference was however not significative.

Table 2:- Number of lesions on wounded and non-wounded mango fruit-halves inoculated with C. gloeosporioides, 8 days after treatment in the laboratory.

\begin{tabular}{|l|l|l|l|l|l|l|l|}
\hline \multicolumn{4}{|l|}{} & \multicolumn{3}{l|}{ Mean number of lesions per fruit } & \multicolumn{3}{l|}{ Number of diseased fruit ${ }^{\mathrm{a}}$} \\
\hline Treatment & Wounded & Non-wounded & Mean $^{\mathrm{b}}$ & Wounded & Non-wounded & Mean \\
\hline Control (inoculated) & 77 & 201 & $138 \mathrm{~A}$ & 3 & 3 & 3 \\
\hline Sonata & 15 & 15 & $15 \mathrm{~B}$ & 3 & 2 & 2.5 \\
\hline Serenade & 5 & 20 & $12 \mathrm{~B}$ & 3 & 2 & 2.5 \\
\hline Control (non-inoculated) & 0 & 0 & $0 \mathrm{~B}$ & 0 & 0 & 0 \\
\hline
\end{tabular}

${ }^{a} \mathrm{n}=4$ mangoes/treatment

b Treatments followed by the same letter are not significantly different $(P<0.05)$. A generalized linear mixed model was used for ANOVA (PROC GLIMMIX, SAS 9.4), and Fisher's LSD was used for the mean separation.

\section{Effect of curative treatment with biofungicides on mango Anthracnose:-}

The results for the post-harvest treatments fruits naturally exposed to C. gloeosporioides in the field, showed that all mangoes (100\%) developed symptoms of anthracnose for the control. Treatment with Sonata and Serenade allowed getting 53\% and $67 \%$ of fruits respectively ripe without infection (Table 3). This level of efficacy was similar to those obtained by treating the fruits with azoxystrobin and thiophanate methyl.

The non-treated control had significantly higher lesions than the other treatments. Treatment with the fungicides, thiophanate methyl and azoxystrobin resulted in significantly less lesions per fruit than Sonata and Serenade. The difference was significative with Sonata but not with Serenade.

Table 3:- Effect of post-harvest treatments with biofungicides on the control of pr-established infection of mango anthracnose after 8 days of incubation in the laboratory

\begin{tabular}{|c|c|c|}
\hline Treatment & Mean number of lesions per mango ${ }^{\mathrm{a}}$ & ${\text { Disease-free fruits }(\%)^{\mathrm{ab}}}^{0 \mathrm{~A}}$ \\
\hline Control & $140 \mathrm{~A}$ & $53 \mathrm{~B}$ \\
\hline Sonata & $55 \mathrm{~B}$ & $67 \mathrm{~B}$ \\
\hline Serenade & $31 \mathrm{BC}$ & $60 \mathrm{~B}$ \\
\hline Azoxystrobin & $23 \mathrm{C}$ & $67 \mathrm{~B}$ \\
\hline
\end{tabular}


a Treatments followed by the same letter are not significantly different $(P<0.05)$. A generalized linear mixed model was used for ANOVA (PROC GLIMMIX, SAS 9.4), and Fisher's LSD was used for the mean separation.

${ }^{b} \mathrm{n}=15$ mangoes/treatment

\section{Discussion:-}

Wounding the fruits prior to inoculation did not lead to higher infection. In the contrary inoculated non-wounded fruits had more lesions per fruit. This suggests that $C$. gloeosporioides is not a wound pathogen as for Colletotrichum horii on persimmon, and in contrast to Colletotrichum acutatum on avocado (Everett, 1997). Postharvest treatment with both Sonata and Serenade resulted in significant reduction in the mean number of lesions per fruit, when they were applied prior to the inoculation. The biocontrol products Sonata and Serenade were very effective in prophylactic treatment of harvested fruits in the laboratory. Anthracnose control by Bacillus species has been reported in several studies. The results of the present experiments confirm the observations of Senghor et al. (2007) indicating that B. subtilis LB5 provided good control of anthracnose on mango in Taiwan. In addition, Korsten et al. (1994) showed that B. subtilis B246 controlled anthracnose on avocado. Moreover, Douville et al. (1992) reported that the disease incidence and severity of anthracnose of alfalfa seedlings were significantly reduced by treatment with $B$. subtilis. The actual results are still is in line with the report of Peralta (2004) showing excellent activity of Bacillus subtilis (QST 713 strain) in reducing the severity of mango anthracnose.

Post-infection application of the biocontrol products revealed that treatments with Serenade and Sonata resulted in significantly fewer lesions per fruit, as well as significantly more disease-free (= marketable) fruits. This suggest that, in addition to a protective action, the biocontrol agents provide a curative activity at post infection stage, allowing them to still protect the fruit even after infection. A use of Serenade and Sonata, in combination with other good practices like sanitation, as a substitute for systemic fungicides could be therefore suggested. In fact, the level of efficacy obtained through treatment with Serenade and Sonata was similar to those obtained by the control treatment using the reference synthetic fungicides azoxystrobin and thiophanate methyl. In addition, the biocontrol products offer the advantage of being suitable for use after harvest, a stage where they combine efficacy and safety to the consumer, unlike synthetic fungicides.

To date, the management of mango anthracnose has relied heavily on the use of fungicides. Products like benzimidazoles and strobilurins have showed good efficacy but their use has come into question due to development of resistance by Colletotrichum species. According to Kumar et al. (2007), Colletotrichum gloeosporioides was moderately resistant to thiophanate-methyl in Andhra Pradesh, India. In addition, Hu et al. (2015) showed that resistance to azoxystrobin and thiophanate methyl existed in Colletotrichum siamense from peach and blueberry in South Carolina. Adding biocontrol products into the basket of control tools against mango anthracnose would help minimize the risk of resistance, as well as reduce negative impact to the environment, the field operators and the consumer downstream.

\section{Literature Cited:-}

1. Arauz, L.F. (2000): Mango anthracnose: economic impact and current options for integrated management. Plant Disease, 84: 600-611.

2. Conway, W.S., Sams C.E, Abbott J., and Bruten B.D. (1991): Post-harvest treatment of apple fruit provides broadspectrum protection against post-harvest pathogens. Plant Disease, 75: 620-622.

3. Diedhiou, P. M., Mbaye, N., Dramé, A., and Samb, P.I. (2007): Alteration of post-harvest disease of mango (Mangifera indica) through production practices and climatic factors. African Journal of Biotechnology 6: 1087-1094.

4. Diedhiou, P.M., Diallo, Y., Faye, R., Mbengue, A.A., and Sene, A. (2014a): Efficacy of different fungicides against mango anthracnose in Senegalese Soudanian agroclimate. American Journal of Plant Sciences 5: 22242229.

5. Diedhiou, P.M., Diop, S.A.G., Mbaye, N., Diedhiou, I., Diallo, Y., Faye, R., and Samb, P.I. (2014b): Mango rotting in southern Senegal, a big phytosanitary challenge. International Journal of Biosciences 5: 183-188.

6. Dodd, J.C., Prusky, D., and Jeffries, P. (1997): Fruit diseases. In: Litz, R.E. (ed.) The Mango: Botany, Production and Uses. CABI, pp. 257-280.

7. Douville, Y., and G. J. Boland. (1992): A note on the antibiotic properties of Bacillus subtilis against Colletotrichum trifolii. Phytoprotection 73: 31-36. 
8. Drosdoff, M. (1972): Soil micronutrients. Pages 150-162 in Soils of the humid tropics. National Academy of Sciences, Washington, D.C.

9. Dutta, B. K., and Bremmer, E. (1981): Trace elements as plant chemotherapeutants to control Verticillium wilt. Zeitschrift für Pflanzenkrankheiten und Pflanzenschutz 88: 405-412.

10. Govender, V., and Korsten, L. (2006): Evaluation of different formulations of Bacillus licheniformis in mango pack house trials. Biological Control 37: 237-242.

11. Hewajulige, I.G.N., Wijeratnam, WRS. (2010): Alternative postharvest treatments to control anthracnose disease in papaya during storage. Fresh Produce 4: 15-20.

12. Hu, M-J, Grabke, A., Dowling, M.E., and Schnabel G. (2015): Resistance in Colletotrichum siamense from peach and blueberry to thiophanate methyl and azoxystrobin. Plant Disease 99: 806-814.

13. Janisiewicz, W.J., and Korsten, L. (2002): Biological control of postharvest diseases of fruits. Phytopathology 40: 411-441.

14. Jesus Júnior, W. C., Vale, F.X.R., Coelho, R.R., Hau, B., Zambolim, L., and Berger, R.D. (2004) Management of angular leaf spot in common bean (Phaseolus vulgaris L.) with molybdenum and fungicide. Agronomy Journal 96: 665- 670.

15. Kefialew, Y., and Ayalew, A. (2008): Postharvest biological control of anthracnose (Colletotrichum gloeosporioides) on mango (Mangifera indica). Postharvest Biology and Technology Journal 50: 8-11.

16. Korsten, L., De Villiers, E.E., Duvenhage, J.A., and Kotze, J.M. (1994): Control of avocado preharvest diseases with Bacillus subtilis and fungicide sprays. South African Avocado Growers Association Yearbook 17: 32-34.

17. Kumar, A.S., Reddy, N.P.E., Reddy, K.H., and Devi, M.C. (2007): Evaluation of fungicidal resistance among Colletotrichum gloeosporioides isolates causing mango anthracnose in Agri Export Zone of Andhra Pradesh, India Plant Pathology Bull. 16: 157-160.

18. Mbaye, N. (2006) : Inventaire et caractérisation des champignons phytopathogénes responsables des maladies post-récoltes chez deux variétés de mangues (Mangifera indica L), Kent et Keitt, destinées à l'exportation dans la zone des Niayes du Sénégal. Dissertation: Département biologie végétale: Université Cheikh Anta Diop, 105 p.

19. McMillan, R.T. (1984): Control of mango anthracnose with foliar sprays. Proc. Florida State Horticulture Society 97: 344-345.

20. Mengel, K., and Kirkby, E.A. (2001): Principles of Plant Nutrition (5th ed.) (p. 480). Dordrecht: Kluwer Academic Publishers.

21. Miller, V.R., and Becker, Z.E. (1983): The role of microelements in cotton resistance to Verticillium wilt. Sel'sk. Biology 11: 54-56.

22. Nelson, S.C. (2008): Mango anthracnose (Colletotrichum gloeosporioides). Plant Disease. Department of Plant and Environmental Protection Sciences, College of Tropical Agriculture and Human Resources, University of Hawaii, Manoa, pp.1-9.

23. Niane, A.B. (1984) : Etudes cartographiques et agro-pedologiques des sols de plateau de basse Casamance. Mémoire de stage présenté pour la confirmation. Institut Senegalais de Recherche Agricole (ISRA), 104 p.

24. Peralta, G.A. (2004): Field evaluation of Bacillus subtilis (QST 713 strain) for the control of mango anthracnose. Philippines Univ. Los Banos, College, Laguna (Philippines). National Crop Protection Center.

25. Polanco, L.R., Rodrigues, F.A., Moreira, E.N., Duarte, H.S.S., Cacique, I.S., Valente, L.A., Vieira, R. F., Paula Júnior, T. J., and Vale, F. X. R. (2014) : Management of anthracnose in common bean by foliar sprays of potassium silicate, sodium molybdate, and fungicide. Plant Disease 98: 84-89.

26. Senghor, A.L., Liang, W.J, and Ho, W.C. (2007): Integrated control of Colletotrichum gloeosporioides on mango fruit in Taiwan by the combination of Bacillus subtilis and fruit bagging, Biocontrol Science and Technology 17: 865-870.

27. Sivakumar, D., Jiang, Y., and Yahia, E.M. (2011): Maintaining mango (Mangifera indica L.) fruit quality during the export chain. Food Research International 44: 1254-1263.

28. Sugar, D.T.L., Sanchez, E.E.R, and Khemira, E. (1997): Management of nitrogen and calcium in pear trees for enhancement of resistance of post-harvest decay. Horticultural Technology 2: 382-387.

29. Sundravadana, S., Alice, D., Kuttalam, S., and Samiyappan, R. (2006): Control of mango anthracnose by azoxystrobin. Tunisian Journal of Plant Protection 1: 109-114.

30. Van Deventer, F.J. (2011): Environmentally friendly approach to postharvest quality maintenance of mango (Mangifera indica L.) cv. 'Tommy Atkins' \& 'Kent'. Dissertation: Faculty of Natural and Agricultural Sciences at University of Pretoria, $127 \mathrm{p}$. 
31. Wilson C.L., Solar, J.M., El-Ghaouth, A., and Wisniewski, M.E. (1997): Rapid evaluation of plant extracts and essential oils for antifungal activity against Botrytis cinerea. Plant Disease 81: 204-210.

32. Everett, K.R. (1997): Proceedings from Conference '97: Searching for Quality. Joint Meeting of the Australian Avocado Grower's Federation, Inc. and NZ Avocado Growers Association, Inc., 23-26 September 1997. J. G. Cutting (Ed.). Pages 55-68.

33. Liu, X., Jing-Ze, Z., Lei, C. and Kevin, D. H. (2010): Biology of Colletotrichum horii, the causal agent of persimmon anthracnose, Mycology 1:4: 242-253 